\title{
Resistance Test Eleusine Indica L. Gaertn On Glyphosate Herbicide
}

\author{
Junita Br. Nambela ${ }^{1}$ \\ \{junitanambela@pertanian.go.id ${ }^{1}$ \} \\ ${ }^{1}$ Balai Pengkajian Teknologi Pertanian Papua Barat, Indonesia
}

\begin{abstract}
Eleusine indica is one of the weeds that the existence detectable almost field or plant cultivation, especially in oil palm plantation areas estate. One of the methods to control this weed is with herbicide applications. The used of one kind of herbicide with a continuously and long time can cause weed resistance to this kind of herbicide. The researched purposed is to determine the response of two population E. indica to glyphosate herbicide. The research used Randomized Block Design with three replication and five variations of treatment dose for an herbicide that are: 60,75 grams active ingredients/ha, 121,5 grams active ingredients/ha, 243 grams active ingredients/ha, 486 grams active ingredients/ha and 972 grams active ingredients/ha. This researched at Research Installation Faculty of Agriculture, University of North Sumatra with \pm 25 meters over the sea. The highest rate of herbicide resistance was found in the ER1 population at 6 Week After Application where the Lethal Dose 50 glyphosate value in this population was 16 times greater than the comparison population. E. indica from ecotype ER1 has been resistant to glyphosate herbicide. Giving glyphosate herbicides significantly affected E. indica originating from both ecotypes, namely ER1 and ESP on weed number parameters surviving at 3 Week After Application and 6 Week After Application. While the administration of glyphosate herbicide has a significant effect on E. indica from ESP ecotypes on the parameters of the number of tillers at 6 Week After Application.
\end{abstract}

Keywords: Resistance, Glyphosate, Herbicide, Eleusine indica L. Gaertn

\section{Introduction}

Weed is a plant that grows in a place and its existence is undesirable because it interferes with cultivated plants or can interfere with human activities. In the context of the weed-crop ecology, weeds are plants that originate from the natural environment and continuously interfere with plants and human activities in trying to cultivate the plants [1].

Eleusine indica L. Gaertn is one example of a weed whose existence can be found in almost all plantations or plant cultivation, especially in annual plantations such as oil palm (Elaeis guineensis Jacq. L.). The existence of these weeds is quite disturbing in the production area which includes producing plants and immature plants as well as in the seedling area, especially in main-nursery. Whereas the pre-nursery can still be ignored because the population can still be tolerated.

Lately, it has been known that problems occur as a result of controlling weed populations carried out by humans. This problem especially occurs as a result of chemical weed control (chemist), which is in the form of increased immunity from weeds controlled by certain herbicides. This is then known as a 'resistance'. Herbicide resistance is the ability inherited by plants to survive and reproduce even though a herbicide is applied with a dose that will usually kill plants of the wild species. In plants, resistance can occur naturally due to selection 
or can be stimulated through techniques such as genetic engineering. Resistance can occur in plants as a result of random and rare mutations. Several cases in the world show that herbicides cause plants to be susceptible to death if certain herbicides are applied but in the same population some plants are resistant to herbicides. Henceforth, these plants will grow without competition from susceptible and reproducing plants. If treatment with the herbicide continues, the resistant plants will succeed in multiplying and become increasingly dominant in the population [2].

Today more weeds are resistant to herbicides. This can occur because the weed is controlled with certain single herbicides repeatedly. Continuous use of a single herbicide will result in the growth of resistant weed. As a result of the continuous use of one type of herbicide in one field, there will be changes in dominance in weed communities from sensitive species to tolerant species [3].

The author conduct this research on resistant weeds because of a unique phenomenon that occurs in one of the oil palm nursery areas, which is located at oil palm nursery area of Palm Oil Plantation of Perkebunan Nusantara where the population of E. indica cannot be controlled with glyphosate after it is being used for \pm 26 years continuously. Later this problem was anticipated by increasing the dosage application but eventually, this was also not helpful because weed tended to be insensitive (tolerant/resistant) to glyphosate.

E. indica belongs to the family Poaceae, genus Eleusine. It is a seasonal grass with ribbonleafed, forming a little tight clump and low. The rooting is not deep but thick and strong gripping the soil so it is difficult to pull it out. It breeds mainly with seeds, the seeds could be so many and small and easily got carried away [4]. E. indica blooms throughout the year and each plant can produce up to 140,000 seeds each season [5].

These weeds grow on moist soil or in the area that not too dry and open or slightly shaded. The area of spread covers 0-1600 meters above sea level. The clearing is difficult too because of its stem books, especially the bottom have the potential to grow new shoots. The application of both contact and systemic herbicides is generally more effective for controlling them (Nasution, 1983). The study aims to determine whether the population of E. indica from oil palm nurseries at Seberang Palm Oil Plantation PTPN II has been resistant to glyphosate herbicide.

Glyphosate is an herbicide used throughout the world. Glyphosate was first discovered in 1970 by John E. Frans, who worked for Monsanto. Glyphosate herbicides have been popular since they were first marketed in 1974 [6]. It is an herbicidal glycine derivative group, nonselective, applied as a post-growth herbicide, is systemic and absorbed by plant leaves, but is immediately inactive if it enters the soil. Glyphosate is a 5-enolpiruvylshikimate-3-phosphatesynthase (EPSPS) inhibitor, an enzyme that affects aromatic acid biosynthesis. With glyphosate, an amino acid synthesis which is important for protein formation will be inhibited (Djojosumarto, 2006).

Long-term use of herbicides needs to consider the possibility of weed resistance to the application of it. Resistance property can be inherited from one generation to the next. The first resistance in 2,4-D in 1945, the Dalapon in 1953, atrazine in 1958, picloram in 1963, trifluralin in 1963, diclofop in 1977, trialate in 1962, chlorsulfuron in 1982 and glyphosate in 2003. The development of resistant weed populations is much faster (3-5 years) than time and money invested in research [7].

Consequences of repeated use of the same herbicide (same type of active ingredient or working method) over a long period of time in an area will lead to two possible problems that arise in the area; that is the dominance of herbicide-resistant weed populations or herbicidetolerant weed dominance. In a controlled weed population using one type of herbicide with 
satisfactory results, it is possible that one individual of the millions of individuals given herbicides have a gene that makes the individual immune to the herbicide. These immune individuals grow normally and produce regeneration, a number of individuals who are also resistant to the same herbicide in the next herbicide application. And so on repeatedly, every application of the same herbicide will kill sensitive individuals and leave resistant individuals. The number of resistant individuals at one time becomes significant and causes failure in management [8].

The best defense against herbicide resistance is to use different ways of how herbicides work during the same year or rotating different herbicides each year, crop rotation, and cultivation techniques will help reduce selection [9].

Based on the above problems, the authors are interested in conducting research to test the resistance of E. indica weed to glyphosate herbicides.

\section{Research Method}

This research was conducted in the Research Installation of the Faculty of Agriculture, University of North Sumatra, Medan with an altitude of \pm 25 meters above sea level. The research was conducted from June 2011 to August 2011.

The material used in this study consisted of E. indica seeds taken from two different ecological types and different histories of weed control. The first population came from the oil palm nursery across the palm oil plantation, Langkat as the ER1 population. The oil palm nursery area where the ER1 population was found has been sprayed with glyphosate for 26 years continuously with a dose of $\pm 1 \mathrm{~L}$ Glyphosate per hectare ( $486 \mathrm{~g} \mathrm{ba} / \mathrm{ha})$ and continues to increase from year to year to now to $2.5 \mathrm{~L}$ per hectare $(1,215 \mathrm{~g} \mathrm{ba} / \mathrm{ha})$. Recently it has been detected that glyphosate is no longer able to control E. indica in the area; the second population is the population of the University of North Sumatra Faculty of Agriculture which is used as a comparison population and is referred to as the ESP population; glyphosate (Roundup Biosorp 486 SL), topsoil, sand, compost, and polybag.

The tools used in this study included the "Solo" knapsack, name labels, envelopes, scales, measuring cups, and other tools that support this research.

The population of E. indica was treated with glyphosate as many as five doses each and each treatment was made in three replications. The treatment was arranged in a non-factorial randomized group design [10]. Five levels of glyphosate treatment used were: $\mathrm{G} 1=60.75 \mathrm{~g}$ ba glyphosate/ha; G2 = $121.5 \mathrm{~g}$ ba glyphosate/ha; G3 = $234 \mathrm{~g}$ ba glyphosate/ha; G4 = $486 \mathrm{~g}$ ba glyphosate/ha; G5 = $972 \mathrm{~g}$ ba glyphosate/ha. The parameters observed were the amount of weed survival, number of tillers, dry weight, median lethal dose 50 (LD 50).

\section{Result and Discussion}

\subsection{The number of survival weeds}

The percentage of E. indica that survived on 3 weeks after application (WAA) and 6 WAA for each polybag was shown in table 1 . The application of glyphosate herbicide significantly affected the percentage of E. indica that survived. 
Table 1. Average E. indica survival in observations of 3 WAA and 6 WAA.

\begin{tabular}{|c|c|c|}
\hline \multirow{2}{*}{ Herbicide (grams active ingredients/ha) } & \multicolumn{2}{|c|}{$\%$ Survival } \\
\hline & 3 WAA & 6 WAA \\
\hline $\mathrm{A} 1=\mathrm{G} 1:$ Glyphosate 60,75 applying on ER1 & $95,00 \mathrm{a}$ & $83,33 \mathrm{ab}$ \\
\hline $\mathrm{A} 2$ = G2: Glyphosate 121,5 applying on ER1 & $95,00 \mathrm{a}$ & $85,00 \mathrm{a}$ \\
\hline A3 = G3: Glyphosate 243 applying on ER1 & $80,00 \mathrm{~b}$ & $73,33 b$ \\
\hline A4 = G4: Glyphosate 486 applying on ER1 & $68,33 \mathrm{bc}$ & $58,33 \mathrm{bc}$ \\
\hline A5 = G5: Glyphosate 972 applying on ER1 & $63,33 \mathrm{bc}$ & $56,66 \mathrm{bc}$ \\
\hline A6 = G1: Glyphosate 60,75 applying on ESP & $90,00 \mathrm{a}$ & $78,33 \mathrm{ab}$ \\
\hline A7 = G2: Glyphosate 121,5 applying on ESP & $68,33 \mathrm{bc}$ & $46,66 c$ \\
\hline A8 = G3: Glyphosate 243 applying on ESP & $36,66 \mathrm{~d}$ & $30,00 \mathrm{~d}$ \\
\hline A9 = G4: Glyphosate 486 applying on ESP & $33,33 d$ & $15,00 \mathrm{~d}$ \\
\hline A10= G5: Glyphosate 972 applying on ESP & $0,00 \mathrm{e}$ & $0,00 \mathrm{e}$ \\
\hline Contrast Test & \multicolumn{2}{|c|}{ Statement } \\
\hline $\mathrm{C} 1: \mathrm{A} 1, \mathrm{~A} 2, \mathrm{~A} 3, \mathrm{~A} 4, \mathrm{~A} 5$ vs A6,A7,A8,A9,A10 & * & * \\
\hline
\end{tabular}

Table 1 shows that the highest percentage of E. indica that survived both on observations of 3 WAA and 6 WAA was found in A1 and A2 (Glyphosate 60,75 and 121,5 in ER1) of 95\%. While the lowest percentage of E. indica was found in A10, namely G5 (Glyphosate 972 at ESP) of $0 \%$ both at 3 WAA and 6 WAA.

In table 1 it can be seen that in treatment A8, the application of glyphosate at a dose of 243 $\mathrm{g}$ ai/ha had a significant effect on the death of E. indica population ESP compared to the ER1 population. At this dose, E. indica that survived from the ESP population was $36,6 \%$ (3 WAA) and $30 \%$ (6 WAA), less than half of the ER1 population whose percentage was $80 \%$ ( 3 WAA) and $73,3 \%$ (6 WAA).

The $\mathrm{C} 1$ contrast test comparing the percentage of survival weeds from ecotypes ER 1 and ESP both at 3 WAA and 6 WAA showed that the treatment of glyphosate herbicides was significantly different when compared with each other for E. indica control.

The following is a graph of the comparison of E. indica that survived 3 WAA and 6 WAA in the ER1 and ESP populations. 


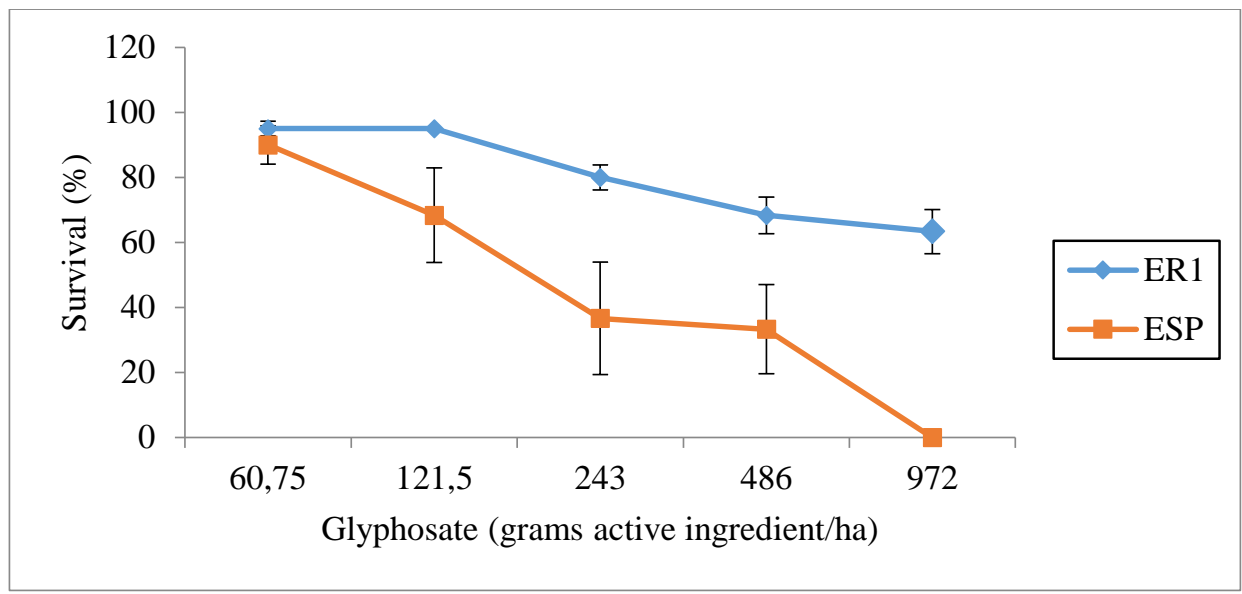

Figure 1. Comparative graph of Eleusine that survives 3 WAA populations ER1 and ESP

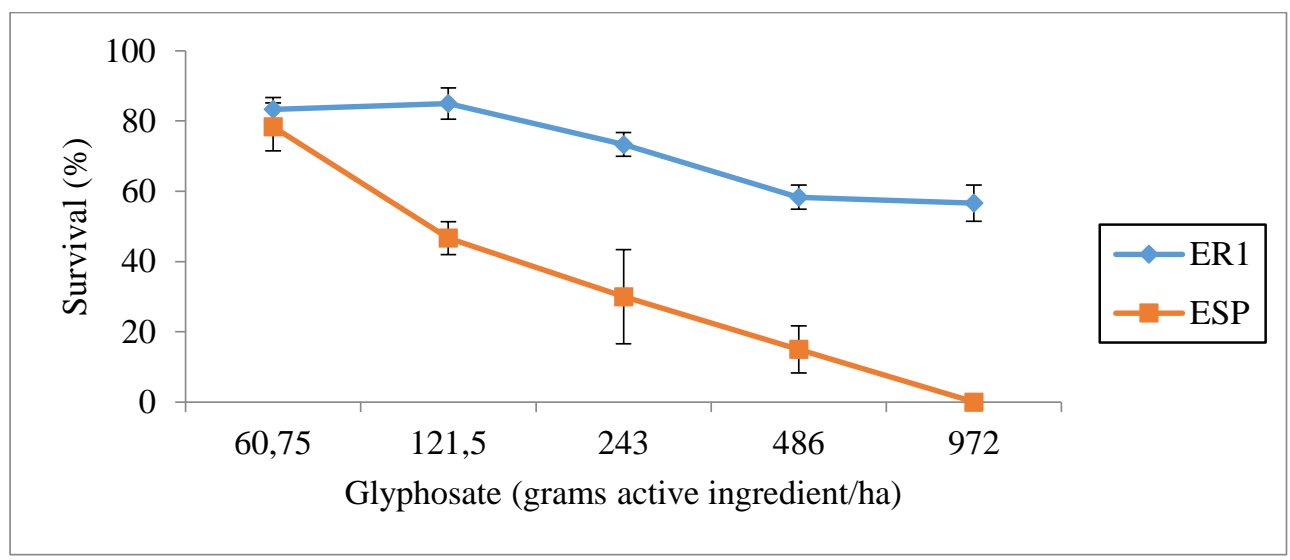

Figure 2. Comparison of Eleusine graphs that survived 6 WAA of ER1 and ESP populations

Figures 1 and 2 show that there are significant differences in Eleusine's survival from the two populations tested which started from a dose of $121,5 \mathrm{~g} \mathrm{ba} / \mathrm{ha}$ until the largest dose was $972 \mathrm{~g} / \mathrm{ha}$. Through the picture, it can also be seen that the best dose that can be used to control the ESP population is the highest dose of $972 \mathrm{~g}$ ba/ha because at this dose all Eleusine dies ( $0 \%$ at 3 WAA and 6 WAA) so that control is successfully carried out. But this is not the case with the ER1 population because at the same dose Eleusine can survive even reaching half of the tested population, $63,3 \%$ at $3 \mathrm{WAA}$ and $56,6 \%$ at 6 WAA.

In addition, below is also a graph of the comparison of E. indica that survives 3 WAA and 6 WAA in the ER2 and ESP populations.

\subsection{Number of tillers}

Many tillers produced by E. indica in each polybag observed at 6 WAA can be seen in table 2 . 
Table 2. Average number of E. indica tillers in each polybag at 6 WAA observations.

Herbicide (grams active ingredients/ha)

Number of Tillers

\begin{tabular}{lc}
\hline A1 $=$ G1: Glyphosate 60,75 applying on ER1 & $20,67 \mathrm{c}$ \\
A2 $=$ G2: Glyphosate 121,5 applying on ER1 & $21,33 \mathrm{bc}$ \\
A3 $=$ G3: Glyphosate 243 applying on ER1 & $18,67 \mathrm{c}$ \\
A4 = G4: Glyphosate 486 applying on ER1 & $39,33 \mathrm{a}$ \\
A5 = G5: Glyphosate 972 applying on ER1 & $28,33 \mathrm{bc}$ \\
A6 = G1: Glyphosate 60,75 applying on ESP & $13,33 \mathrm{~cd}$ \\
A7 = G2: Glyphosate 121,5 applying on ESP & $28,00 \mathrm{~b}$ \\
A8 = G3: Glyphosate 243 applying on ESP & $7,33 \mathrm{~d}$ \\
A9 $=$ G4: Glyphosate 486 applying on ESP & $5,00 \mathrm{~d}$ \\
A10= G5: Glyphosate 972 applying on ESP & $0,00 \mathrm{e}$ \\
\hline
\end{tabular}

\begin{tabular}{lc}
\hline Contrast Test & Statement \\
\hline $\mathrm{C} 1: \mathrm{A} 1, \mathrm{~A} 2, \mathrm{~A} 3, \mathrm{~A} 4, \mathrm{~A} 5$ vs A6,A7,A8,A9,A10 & $*$ \\
\hline
\end{tabular}

Table 2 shows that the treatment of glyphosate herbicide significantly affected the number of Eleusine tillers for the two populations tested.

In the table it can be seen that for glyphosate treatment, A1 to A10, the highest number of Eleusine tillers was at a dose of $486 \mathrm{~g}$ ba/ha, which was 39,33 total amount found in the ER1 population, the amount was almost twice as large as the population applied with the smallest dose for the population is $60,75 \mathrm{~g} \mathrm{ba} / \mathrm{ha}$ which has as many as 20,67 tillers. Whereas the number of tillers was the least found in the ESP population with an application dose of $972 \mathrm{~g}$ $\mathrm{ba} / \mathrm{ha}$ whose tillers no longer exist up to $6 \mathrm{WAA}$.

$\mathrm{C} 1$ contrast test showed that the glyphosate herbicide was an effective treatment to control Eleusine. This is implied by the response of glyphosate which is significantly different from the number of tillers if applied to Eleusine. Although there were still deviations where the highest number of tillers for the ER1 population was found in the A4 treatment, the application of glyphosate $486 \mathrm{~g}$ ba/ha and for the ESP population was found in A7, the application of glyphosate $121,5 \mathrm{~g}$ ba/ha.

The following below is a graph of the comparison of the average number of tillers Eleusine 6 WAA population of ER1 and ESP taken for each polybag. 


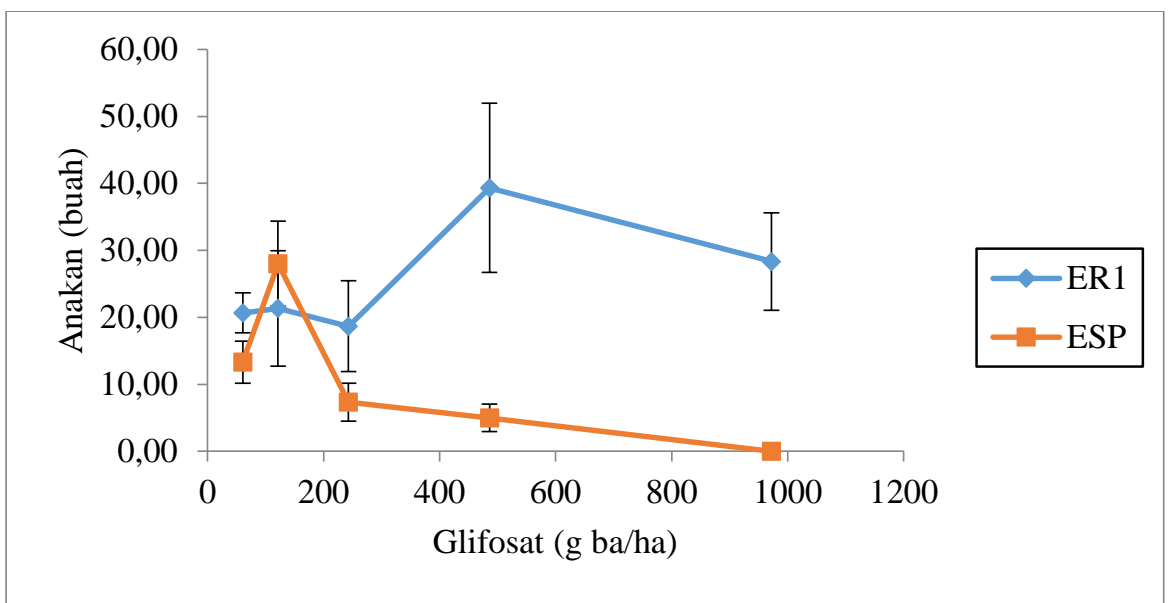

Figure 3. Graph of comparison of the number of Eleusine 6 tillers in the ER1 and ESP populations

In Figure 3 it can be seen that the application of glyphosate has a significant effect on the number of tillers produced by Eleusine in the ESP population but not in the ER1 population. The best dose of glyphosate to use according to the average number of tillers is the highest dose of $972 \mathrm{~g}$ ba/ha which can kill Eleusine and its tillers until it reaches 0 (zero).

\subsection{Weed dry weight}

From the observation data of E. indica dry weight, it can be seen that the treatment of herbicides both glyphosate and paraquat had no significant effect on E. indica dry weight at 6 WAA. The E. indica dry weight average data can be seen in Table 3.

Table 3. Average of E. indica dry weight in each polybag on observation of 6 WAA

Herbicide (grams active ingredients/ha)

Dry Weight (gram)

\begin{tabular}{|c|c|}
\hline $\mathrm{A} 1=\mathrm{G} 1 \mathrm{:}$ Glyphosate 60,75 applying on ER1 & 19,41 \\
\hline $\mathrm{A} 2=\mathrm{G} 2$ : Glyphosate 121,5 applying on ER1 & 21,12 \\
\hline A3 = G3: Glyphosate 243 applying on ER1 & 15,68 \\
\hline A4 = G4: Glyphosate 486 applying on ER1 & 15,64 \\
\hline A5 = G5: Glyphosate 972 applying on ER1 & 12,93 \\
\hline A6 = G1: Glyphosate 60,75 applying on ESP & 17,70 \\
\hline A7 = G2: Glyphosate 121,5 applying on ESP & 13,96 \\
\hline A8 = G3: Glyphosate 243 applying on ESP & 3,23 \\
\hline A9 = G4: Glyphosate 486 applying on ESP & 2,04 \\
\hline $\mathrm{A} 10=\mathrm{G} 5:$ Glyphosate 972 applying on ESP & 0,00 \\
\hline
\end{tabular}


From table 3 above, it can be seen that the treatment of glyphosate herbicide has no significant effect on weed dry weight. For the treatment of glyphosate application, the highest average dry weight amount was 21,11 grams for ER1 ecotypes which were sprayed with glyphosate at a dose of 121,5 $\mathrm{g}$ ai/ha and for the ecotypes ESP the biggest weight was 17,7 grams which were sprayed with the smallest dose of glyphosate $60,76 \mathrm{~g}$ ai/ha. Whereas for the smallest average number was 15,64 grams for ER1 ecotypes which were sprayed with glyphosate at a dose of $486 \mathrm{~g}$ ai/ha and 0 grams for ESP ecotypes which are sprayed with glyphosate with the largest dose of $972 \mathrm{~g}$ ai/ha.

\subsection{Lethal Dose 50 (LD50)}

Based on the number of weeds surviving from the five levels of herbicide studied, the LD50 value of the herbicide was tested against E. indica. The LD50 value of each can be seen in table 4.

Table 4. LD50 values of glyphosate herbicide applied to E. indica.

\begin{tabular}{|c|c|c|}
\hline \multirow{2}{*}{ Duration } & \multicolumn{2}{|c|}{ LD50 (grams active ingredient/ha) } \\
\cline { 2 - 3 } & \multicolumn{2}{|c|}{ Glyphosate } \\
\cline { 2 - 3 } & ER1 & ESP \\
\hline 6 WAA & $1.549,1$ & 91,5 \\
\hline
\end{tabular}

From table 4, it can be seen the LD50 value obtained through calculations based on the number of Eleusine which survives at the five given levels. The highest LD50 value of glyphosate herbicide was found in the application of the ER1 population at 6 WAA which reached $1.549,1 \mathrm{~g} / \mathrm{ha}$. While the ESP population was the most sensitive population of glyphosate which is characterized by a low LD50 value of only 91,5 g/ha. If seen from this value, it is known that the LD50 value of the ER1 population is 16 times the ESP population. This shows the level of resistance of this population has been very high against glyphosate herbicide.

From the results of the study, it can be seen that each Eleusine population with a different ecotype has different responses to various types and doses of herbicides. This can be seen from the variation in response that occurred in Eleusine which was applied by glyphosate herbicide. This variation is due to the presence of internal factors in response to any treatment from outside. This is in accordance with the literature of Moenandir (1990) [11] which states that the internal factors of plants that influence the poisoning power of a herbicide are related to the level of development of a plant that has a different sensitivity to herbicides.

Based on the results of the study it was found that the use of a single glyphosate herbicide for 26 years to control Eleusine weeds originating from the ecotype ER1 had caused an increase in weed resistance to the herbicide. This is consistent with the statement of Chaudhry (2008) [7] which states that long-term use of herbicides needs to consider the possibility of weed resistance to the application of herbicides.

From this study, it is known that Eleusine from the ecotype ER1 is indeed resistant to glyphosate which is often used for its control. This can be seen from the magnitude of the percentage of Eleusine that survives in this population up to 6 WAA which is $56.6 \%$ while for the comparison from the ecotype ESP is $0 \%$. In addition, this can also be seen from the 
comparison of LD50 values from glyphosate herbicides that were applied to two types of populations that applied the herbicide namely ER1 and ESP where the comparative value reached 16: 1. From these data, it is known that the number of glyphosate-resistant Eleusine has dominated the ER1 population so that management efforts have failed. This is in accordance with literature from Purba (2009) [8] which states that the consequences of using the same herbicide (same type of active ingredient or the same way of working) over a long period of time in an area, there are two possible problems that arise in the area; that is the dominance of herbicide-resistant weed populations or herbicide-tolerant weed dominance.

In observational data on the number of tillers taken at $6 \mathrm{WAA}$, there was a significant deviation in the number of tillers for the application of glyphosate herbicides in the ER1 population. This deviation is probably caused by genetic factors from weeds as a factor in resistance to the application of herbicides given. In addition, environmental factors such as weather and growing media also play a role in causing this deviation. This is in accordance with the literature of Sastroutomo (1990) [3] which says that the environment is a unity of all living and dead factors that can affect growth, breeding, or the spread of all types of plants, where the use of certain chemicals can affect plant growth.

Initially, the spraying dose of $486 \mathrm{~g}$ ba/ha for glyphosate was able to control Eleusine weeds and the dosage has long been used to control weeds in the two resistant weed ecotypes. But later this dose is no longer able to control Eleusine and the spraying dose is increased significantly up to twice the original. This is consistent with the statement of Purba (2009) [8] which states that herbicide-resistant weed populations are populations that survive normally at doses that normally kill the population. Based on the results of the research obtained it is known that the hypothesis of Eleisine resistance is true. Therefore, a solution is needed to prevent this problem. One of the most commonly suggested methods by experts is not use a single type of herbicide for a long time but to replace it regularly or rotate herbicides. This is in accordance with the literature of Martin, et al. (2000) who say the best defense against herbicide resistance is to use different ways of working herbicides during the same year or rotating different herbicides each year, crop rotation, and cultivation techniques will help reduce pressure selection.

\section{Conclusion}

The highest rate of herbicide resistance was found in the ER1 population at 6 WAA where the LD50 glyphosate value in this population was 16 times greater than the comparison population. E. indica from ecotype ER1 has been resistant to glyphosate herbicide. Giving glyphosate herbicides significantly affected E. indica originating from both ecotypes, namely ER1 and ESP on weed number parameters surviving at 3 WAA and 6 WAA. While the application of glyphosate herbicide has a significant effect on E. indica from ESP ecotypes on the parameters of number of tillers at 6 WAA.

\section{References}

[1] R. J. Aldrich, Weed-Crop Ecology: Principles in Weed Management. Breton publishers, 1984.

[2] Anonim, "Resistance of Herbicide," 2011. [Online]. Available: http://www.anrcatalog.ucdavis.edu.

[3] S. S. Sastroutomo, "Weeds Ecology," PT Gramedia Pustaka Utama. Jakarta, 1990. 
[4] U. Nasution, "Weed and its Control in Rubber Plantation North Sumatera dan Aceh," Plant. Res. Dev. Cent. Tanjung Morawa, 1984.

[5] L. J. Lee and J. Ngim, "A first report of glyphosate -resistant goosegrass (Eleusine indica (L) Gaertn) in Malaysia," Pest Manag. Sci. Former. Pestic. Sci., vol. 56, no. 4, pp. 336-339, 2000.

[6] C. Cox, "Herbicide Factsheet-Glyphosate," J. pestic. reform, vol. 24, pp. 10 $15,2004$.

[7] O. Chaudhry, "Herbicide-Resistance and Weed-Resistance Management," Albert Campbell Coll. Institute, Toronto, Ontario, Canada, 2008.

[8] E. Purba, "Herbicidal Diversity in Weed Control Overcomes Herbicide Resistant Weed and Tolerant Populations," Speech Ina. Perm. Profr. Position Univ. Sumatera Utara, 2009.

[9] C. D. Lee, F. W. Roeth, and A. R. Martin, Herbicide Resistant Weeds. Cooperative Extension, Institute of Agriculture and Natural Resources ..., 2000.

[10] M. K. Bangun, "Experimental Design," Bagian Biometri. Fak. Pertanian. Univ. Sumatera Utara, Medan, 1991.

[11] J. Moenandir, Herbicide Physiology (Weed Science - Book II). Jakarta: Rajawali Pers, 2003.

Steel, R. G. D. dan J. H. Torrie. 1993. Statistical Principles and Procedures A Biometric Approach. PT Gramedia Pustaka Utama, Jakarta. 